\title{
European Medicines Agency's Priority Medicines (PRIME) scheme at 2 years: An evaluation of clinical studies supporting eligible drugs
}

\author{
Emilie Neez, ${ }^{1}$ Thomas Hwang, ${ }^{2}$ Samali Anova Sahoo, ${ }^{3}$ and Huseyin Naci ${ }^{1}$
}

1. Department of Health Policy, London School of Economics and Political Science

2. Program on Regulation, Therapeutics, and Law (PORTAL), Division of Pharmacoepidemiology and Pharmacoeconomics, Harvard Medical School

3. University of Pennsylvania

\section{Correspondence:}

Huseyin Naci, MHS PhD

Department of Health Policy

London School of Economics and Political Science

20 Houghton Street, London WC2A 2AE, UK

Email: h.naci@1se.ac.uk

Phone: +44-(0)20-7955-6874

\section{Conflict of Interest:}

The authors declared no competing interests for this work.

\section{Funding:}

This study was partly funded by the Department of Health Policy at the London School of Economics and Political Science. HN was 2018-19 UK Harkness Fellow in Health Care Policy and Practice, funded by the Commonwealth Fund. HN is also supported by the Higher Education Funding Council in England. EN was supported by LSE Health. TJH was supported by the Swiss Cancer Foundation. Funders did not have any role in the study design; the collection, analysis, and interpretation of data; the writing of the report; or the decision to submit the article for publication. All authors had full access to all of the data in the study and can take responsibility for the integrity of the data and the accuracy of the data analysis.

\section{Word count: 3,744}

\section{Key words:}

European Medicines Agency, pharmaceutical regulation, pharmaceutical regulation, research and development 


\begin{abstract}
The Priority Medicines (PRIME) scheme was launched by the European Medicines Agency (EMA) in 2016 to expedite the development and approval of promising products targeting conditions with high unmet medical need. Manufacturers of PRIME drugs receive extensive regulatory advice on their trial designs. Until June 2018, EMA granted PRIME status to 39 agents, evaluated in 138 studies (102 initiated before and 36 after PRIME eligibility). A third of studies forming the basis of PRIME designation were RCTs and a quarter were blinded. There was no statistically significant difference between trials initiated before and after PRIME designation in terms of randomised design and use of blinding. However, significantly more efficacy studies included a clinical endpoint after PRIME designation than before, and significantly fewer included surrogate measures alone. There were no statistically significant differences between the trial designs of PRIME and non-PRIME-designated products.
\end{abstract}




\section{Introduction}

Drug regulatory agencies are responsible for assessing the clinical efficacy and safety risks of novel therapeutic agents before they can be approved for use in clinical practice. In the European Union, pharmaceutical companies can market their novel products in all member states after receiving a single centralised authorization from the European Medicines Agency (EMA). EMA reviews data submitted by the manufacturer and grants a marketing authorisation for products that have a positive benefit-risk profile.

Similar to other drug regulatory agencies such as the Food and Drug Administration (FDA) in the United States, EMA has sought to expedite the development and approval of new medicines.(1) In 2012, FDA introduced the breakthrough therapy designation to offer expedited development and review for drugs which intend to treat a serious or life threatening condition and indicate "substantial improvement over existing therapies" based on preliminary clinical evidence.(2) FDA's breakthrough therapy designation effectively shortens the development timelines of eligible products.(3)

In 2016, EMA launched the Priority Medicines (PRIME) scheme to parallel the FDA's breakthrough therapy designation. The PRIME scheme is the latest regulatory pathway at the EMA's disposal to expedite the development and approval of new medicines, including conditional marketing authorisations, accelerated assessments, and approvals under exceptional circumstances (Box 1).(4)

According to the EMA, drugs are eligible for inclusion in its PRIME scheme if they have the potential "to offer a major therapeutic advantage over existing treatments, or benefit patients without treatment options".(5) The scheme promises early dialogue on development plans and evidence requirements for approval between the EMA and manufacturers. PRIME allows manufacturers to receive extensive regulatory input on trial design by participating in EMA's Scientific Advice program. Regulatory advice available to manufacturers also involves other stakeholders, including health technology assessment (HTA) bodies such as the National 
Institute for Health and Care Excellence (NICE). Eligible products also benefit from the EMA's accelerated assessment program, which further shortens regulatory review times (150 days with accelerated assessment versus 210 days for regular assessment).

Novel therapeutic agents are eligible for the PRIME designation if they are at an early stage of development. Therefore, EMA makes a judgement about the potential therapeutic value of PRIME drugs on the basis of preliminary data. Given the extensive regulatory advice and input on the clinical testing and development activities of eligible drugs, trials of PRIME drugs would be expected to reflect regulatory and HTA preferences for study designs and endpoints, namely blinded randomised controlled trials that evaluate patient-centred outcomes.

In this study, we evaluate the evidence base on which the EMA determines PRIME eligibility of novel therapeutics. In addition, we describe the characteristics of clinical studies initiated before and after EMA's PRIME designation. Finally, we compare the trial characteristics of drugs with and without PRIME designation in the same indication.

\section{Materials and methods}

Sample of drugs

One researcher $(\mathrm{EN})$ obtained the list of PRIME-designated products reported on the EMA's website.(5) Because PRIME products are removed from this list upon application for a marketing authorisation, products which have applied or received a marketing authorisation were complemented from industry and regulatory press releases.(6) All products granted a PRIME designation before 1 June 2018 were included in the study sample, representing the first two years of the scheme.

For each PRIME product, we characterised the substance type, therapeutic area, indication, and date of PRIME designation using publicly available information from the EMA's webpage.(5) The manufacturer was identified through press releases related to the PRIME 
product. Products which received an orphan designation were identified from the European Commission's 'Register of Designated Orphan Medicinal Products'.(7) Whether any other therapies were approved in Europe for the same indication was determined by searching the EMA's website. We also cross-checked whether PRIME products also received a breakthrough therapy designation from the FDA using sponsor press releases.

Clinical studies of PRIME drugs

EMA does not publicly release information about which studies formed the basis of PRIME designations. One researcher (EN) systematically catalogued and reviewed industry press releases to identify the clinical studies on which the PRIME eligibility was granted. The efficacy results for these studies were compiled from (in order of preference) peer-reviewed journal articles listed on clinicaltrials.gov, other peer-reviewed articles and published conference abstracts which included the trial NCT number, and industry press releases.

For each PRIME product, one researcher (EN) then reviewed the clinicaltrials.gov registry to identify all clinical trials conducted (1) for the same indication as the PRIME indication, and (2) for which the industry sponsor was listed as a trial sponsor or collaborator. Clinicaltrials.gov is a National Institute of Health-maintained, publicly available online registry of clinical studies conducted across many diseases and conditions, and includes a database of study results.(8) Information on studies (e.g. study design, eligibility criteria, key dates) is submitted by trial sponsors and investigators. In cases where the product was acquired during the research and development process, we included both the studies conducted by the initial developer and the new owner. Extension studies, long-term follow up studies, and withdrawn studies were excluded. 


\section{Data extraction}

Data extraction from the identified clinical studies was performed by one researcher $(\mathrm{EN})$ and checked for accuracy by a second (SAS). We first determined if the studies were randomised controlled trials (that is, if randomisation was used to allocate patients into different experimental and control groups). We then noted the study start and completion dates, study phase, comparator treatments, number of participants, and whether blinding was used to mask either participants, carers or investigators (or all) from treatment allocation.(9)

We also extracted information on the primary and secondary endpoints of each clinical study. We then classified study endpoints into 5 categories: clinical efficacy, safety, pharmacodynamics, quality of life, and resource use. Efficacy endpoints were further classified as clinical, clinical scale, or surrogate measures, using a previously used classification.(10,11)

The proportion of studies with randomised designs, active comparators, and blinding, as well as the average number of participants, were compared before and after the PRIME designation for each product. We also compared the proportion of studies reporting different types of endpoints before and after PRIME designation.

\section{Clinical studies of PRIME and non-PRIME drugs}

Characteristics of clinical studies of PRIME-designated drugs were compared to those of similar, "matched", non-PRIME products. For each PRIME product with clinical studies available both before and after the PRIME designation, we identified all other products investigated for the same indication on clinicaltrials.gov. Non-PRIME drugs were eligible for inclusion in our comparator sample if they (1) had their first clinical study registered in clinicaltrials.gov during the same calendar year as those with PRIME designation, (2) had trials conducted both before and after the PRIME designation date, and (3) were not already authorised in Europe (i.e. not being studied for an extension of existing approved indication). 
We extracted data on the design characteristics of clinical studies of eligible matched non-

PRIME drugs, as described above.

\section{Statistical analysis}

We used Fischer's exact tests to characterise the features of clinical studies before and after PRIME designation and to compare the design features of PRIME and non-PRIME drugs (presence/absence of: randomisation, blinding, efficacy, quality of life or resource use endpoint, clinical outcome or surrogate measure). We used non-parametric Kruskall-Wallis test to compare the median numbers of participants between trials before and after PRIME designation, and between PRIME and non-PRIME products. We repeated all analyses in a subgroup of late-stage trials (labelled as phase 2 or later on clinicaltrials.gov).

\section{Informed Consent and Ethics}

Review and approval by an Institutional Review Board was not required for this study.

\section{Results}

PRIME drugs

During the first two years of the scheme, the EMA granted PRIME designation to 39 agents (table 1). Two agents (tisagenlecleucel for B-cell acute lymphoblastic leukaemia and axicabtagene ciloleucel for diffuse large B-cell lymphoma) received a marketing authorisation from the EMA in 2018.(12) Two other agents have applied for a regular and conditional marketing authorisation, respectively. $(13,14) 14$ products were included in the scheme in 2016 , 19 in 2017, and 6 in the first half of 2018. 23 (59\%) products also have an FDA breakthrough therapy designation. Most products are being developed by larger companies (24/39, 61.5\%). 
PRIME drugs were mostly advanced therapies (medicines derived from genes, tissues, or cells $(15))(17 / 39,43.6 \%)$, followed by small molecules $(11 / 39,28.2 \%)$, biologics $(10 / 39$, 25.6\%), and immunological agents $(1 / 39,2.6 \%)$. Approximately a third (12/39) targeted oncology indications. The majority of PRIME drugs had orphan designations (32/39, 82.1\%) and a little over a half $(21 / 39,53.8 \%)$ targeted indications for which no EMA-approved treatments could be identified.

Clinical studies supporting PRIME designation

We were able to identify the most likely source of clinical data that supported the EMA's PRIME designation for 26 drugs. Of these, 14 had a single clinical study available on clinicaltrials.gov. For the remaining 12, clinical studies could be identified from sponsor press releases. No information on the clinical studies forming the basis of PRIME designation was available in publicly available sources for the other $13(33.3 \%)$ drugs.

2 products were granted eligibility at the proof-of-principle stage. The 24 other drugs with data available were granted PRIME designation based on a total of 28 studies: 17 were phase 1 studies, and 11 were phase 2. Only $10(36 \%)$ of these studies were RCTs with 7 placebocontrolled and 3 active or standard-of-care controlled. 7 of these RCTs were blinded. Of the 24 $(86 \%)$ studies which included efficacy endpoints, $12(50.0 \%)$ used a clinical endpoint and 10 (41.7\%) surrogate measures. Table 2 presents publicly available efficacy results from these 28 studies (table S1).

\section{Characteristics of clinical studies before and after PRIME designation}

In total, we identified 148 studies conducted by an industry sponsor evaluating PRIME drugs in their relevant therapeutic indications. We excluded 9 extension studies and long-term follow-up studies, as well as 1 withdrawn study, from the subsequent analyses. Our analysis 
therefore included 138 studies. As shown in figure 1, 102 clinical studies started before PRIME designation while 36 started after.

Table 3 presents the characteristics of clinical studies of drugs before and after PRIME designation. 41/102 (40.2\%) of studies conducted before PRIME designation were RCTs, compared to $9 / 36(25 \%)$ after $(\mathrm{p}=0.112)$. Of 102 studies conducted before PRIME eligibility, $34(33.3 \%)$ were blinded, compared to 7 out of $36(19.4 \%)$ of those conducted after $(p=0.140)$. Median study enrolment was 50 (IQR: 23-128) participants in studies that started before PRIME designation and $56(29-161)$ participants in studies that started after $(\mathrm{p}=0.766)$.

The proportion of studies including a quality of life endpoint was four times higher after PRIME designation than before $(11 / 102,10.8 \%$ vs $16 / 36,44.4 \% ; \mathrm{p}<0.001)$. Only two studies included any measure of resource use (frequency of hospital resource utilisation, number of intensive care unit inpatient days, and reason for hospital resource utilisation).

Most clinical studies included at least one efficacy endpoint, both before and after PRIME designation. About a third of the studies included a clinical endpoint before PRIME designation, whereas over three fourths did after $(33 / 87,37.9 \%$ vs $26 / 33,78.8 \%$; $\mathrm{p}<0.001)$. Of 87 efficacy studies that started before PRIME designation, 35 (40.2\%) only included surrogate measures as efficacy endpoints, compared to 3 of $33(9.1 \%)$ that started after PRIME ( $p<$ $0.001)$.

Comparison to non-PRIME products

For the subset of PRIME drugs with matched non-PRIME drugs in the same indication and with clinical studies initiated in the same year, PRIME products were investigated in a total of 24 studies before the date of PRIME eligibility and 9 after. Non-PRIME products had a total of 18 studies before the PRIME eligibility date of their matched product and 8 after. 8/24 (33.3\%) of PRIME and 13/18 (68.4\%) of non-PRIME studies were RCTs before eligibility 
$(\mathrm{p}=0.028)$, and $3 / 9(33.3 \%)$ and $4 / 8(50 \%)$ after $(\mathrm{p}=0.637)$, respectively (table 4$)$. The use of blinding was less frequent among studies of PRIME products. 7/24 (29.2\%) of PRIME and 13/18 (72.2\%) of non-PRIME trials were blinded before $(p=0.012)$, and $2 / 9(22.2 \%)$ and $2 / 8$ $(25 \%)$ after, respectively.

While 9/20 (45.0\%) of PRIME and 2/12 (16.7\%) of non-PRIME efficacy trials included clinical outcomes before the designation was granted $(p=0.139), 7 / 9(77.8 \%)$ and $4 / 5(80 \%)$ included such outcomes after, respectively. About half of PRIME trials and three quarters of non-PRIME trials reported surrogate measures only before $(11 / 20,55 \%$ vs. $9 / 12,75 \%$; $\mathrm{p}=$ 0.452), compared to about a fifth for both after PRIME eligibility (2/9, 22.2\% vs. $1 / 5,20 \%)$.

Subgroup analysis: late-phase clinical studies

Of the studies identified as phase 2 or later, more adopted randomised designs before than after PRIME eligibility $(26 / 47,55.3 \%$ vs. $9 / 30,30 \% ; \mathrm{p}=0.036)$, and more were blinded before than after PRIME eligibility $(21 / 47,44.7 \%$ vs. $7 / 30,23.3 \%$; $=0.088)$ (table S2). Less than a quarter of the late-stage efficacy trials included a clinical endpoint before PRIME designation, whereas three-fourths did after $(11 / 45,24.4 \%$ vs. $23 / 30,76.7 \%$; p < 0.001). Respectively 15/45 (33.3\%) and 1/30 (3.3\%) of the late-stage trials included only surrogate measures before and after PRIME eligibility $(p=0.002)$.

Median study enrolment was 81 participants (30-282) before PRIME designation and 70 (36-196) after $(\mathrm{p}=0.863)$. Of note, phase 3 studies initiated after PRIME designation enrolled a median of 56 patients (34-241), enrolment varied with study design: the 7 RCTs in our sample included a median of 300 patients (128-520), while the 12 single-arm studies included a median of 37 patients (29-47). 


\section{Discussion}

In this systematic evaluation of the EMA's PRIME scheme, we characterised the clinical studies of eligible products. The majority of drugs were granted PRIME designation based on non-randomised studies that measured surrogate markers alone. Studies initiated after PRIME designation were not more likely to have randomised designs and blinding but were more likely to include clinical endpoints. Median study enrolment was similar for studies initiated before and after PRIME designation. We did not observe any differences between these characteristics of clinical studies of PRIME and non-PRIME drugs.

\section{Evidence to support PRIME designation}

Consistent with existing guidance on PRIME applications,(16) the EMA relied mostly on exploratory data to judge the eligibility of products during the first 2 years of the scheme. For two products, PRIME designation was granted at the proof-of-principle stage. Entry at this very early stage is reserved to SMEs and applicants from the academic sector, in acknowledgement of the difficulty for smaller actors with limited knowledge of the regulatory processes to reach the proof-of-concept stage.(16) All other products with available information obtained PRIME designation following early clinical studies. Most of these studies were small single-arm trials, and nearly half included only surrogate measures. Findings of these studies were not routinely available in the published literature. When available, there was considerable variability in the completeness and method of reporting.

While it was not possible to synthesize the findings of disparate studies measuring heterogeneous outcomes using different scales at various follow-up periods, important insights emerge. All products presented some indication of efficacy, ranging from dose-dependent slowing of disease progression to statistically significant increases in median overall survival. Within the third of the 21 studies with identified results which reported overall response rates as 
the primary measurement of efficacy, the magnitude of the response rates varied greatly, from $50 \%$ to $96 \%$. Another third reported changes from baseline in clinical scale scores or surrogate outcomes. Survival-related benefits were mentioned for only 4 products; 2 products demonstrated statistically significant increases in median progression free survival (asunercept in glioblastoma, of 2 months and polatuzumab vedotin in relapsed and refractory diffuse large B cell lymphoma, of 4.7 months). A single product showed statistically significant gains in overall survival (polatuzumab vedotin, of 7 months).

\section{PRIME designation and trial design}

Evaluating the characteristics of studies initiated after EMA's PRIME designation offers a glimpse of regulatory preference for trial designs. A similar proportion of studies that started after PRIME designation were blinded RCTs as compared to those that started before. Two thirds of the phase 3 studies initiated after the PRIME designation were single-arm studies including small numbers of patients (median: 37). We found that more studies initiated after PRIME designation included clinical outcomes rather than surrogate measures. In late-stage efficacy trials, less than 5\% of studies included surrogate markers alone after PRIME eligibility, compared to a third before. Additionally, almost half of late-stage studies conducted after PRIME designation included quality of life endpoints, which are essential to ensure the validity of cost-effectiveness assessments conducted by HTA bodies.(17) The increased incorporation of quality of life endpoints in clinical studies may reflect scientific advice that includes HTA agency input.(18)

We found no statistically significant difference in the design used and endpoints included in trials for PRIME and non-PRIME products. It is unclear how pharmaceutical manufacturers may interpret and act on the regulatory advice from EMA, and how the PRIME scheme fits into the broader landscape of regulatory pathways and programs at the EMA's disposal. 


\section{Implications for regulatory and clinical practice}

The design and endpoints observed in studies after the PRIME designation likely reflect the influence of both the recent developments towards increased flexibility in granting marketing authorisations and the scheme itself. That PRIME designation is not associated with greater use of trial designs preferred by regulatory agency and HTA bodies, namely blinded RCTs, may reflect the larger trend of non-randomised and uncontrolled evaluations of drugs becoming increasingly common.(19) Many therapies that receive the PRIME designation target relatively small populations. Also, reliance on studies with small sample sizes after the PRIME designation may indicate growing regulatory confidence in learning from even the smallest numbers of patients. PRIME studies fit within this regulatory landscape, which is evolving towards adaptive pathways, and appear consistent with EMA's rethinking of evidence generation over medicines' life-cycle.(20)

The picture of PRIME medicines' evidence base that arises from our analysis also underline the importance of post-approval confirmatory studies. Single-arm trials suffer from a range of biases, such as regression to the mean, patient selection effects, or variability in historical controls, as well as from confounding.(21) Although using surrogate measures has several advantages such as shortening the duration, size and complexity of trials, they also have disadvantages: treatment effects were on average $47 \%$ higher in trials measuring surrogate markers than in trials using patient-relevant outcomes, according to large meta-epidemiological studies. $(22,23)$ As treatments effects shown in early phase studies often fail to be confirmed in later, more robust trials (24-27), there is a need to continuously monitor the therapeutic performance of products labelled as "priority medicines" on the basis of preliminary data. Taken together, our findings suggest that rigorous post-marketing studies should be conducted on PRIME-designated products, and in a timely manner. Currently, most post marketing studies are completed with significant delays.(28) 
Our findings are important to inform clinicians and patients about the quantity and quality of data that supports new medicines. Patients and clinicians generally overestimate the benefits and underestimate the harms associated with new treatments approved by regulatory agencies. $(29,30)$ In addition, they tend to overrate the level of evidence and efficacy indicated by the "breakthrough" and "promising" terminologies, as shown by recent research from the US. $(31,32)$

\section{Limitations}

The results of this study should be interpreted in light of its limitations. First, our evaluation is circumscribed by the information made available by the EMA. For example, the EMA does not disclose its rationale for granting PRIME designation at the product-level, and we were unable to identify the evidence base that supported 13 products based on publicly available information. Similarly, products which were denied PRIME eligibility and the reasons for denial could not be identified, curtailing our ability to compare the research and development trajectory of successful and unsuccessful PRIME applicants. The content of the extensive scientific advice received by manufacturers from the EMA is also not publicly available, preventing the appraisal of the extent to which observed differences in trial endpoints and characteristics before and after PRIME designation are attributable to participation in the scheme. This limitation could be addressed by the EMA by increasing transparency around regulatory processes and decisions.

Second, our sample was small, as the scheme is relatively new. Nevertheless, our study constitutes the first systematic evaluation of the PRIME scheme. Third, our categorisation of trials as before or after PRIME designation, as well as the analysis of their characteristics and endpoints, depends on the accuracy of information available from company press releases and public trial registries. Fourth, trial designs conducted before and after the PRIME designation were at different stages of clinical development and may simply reflect the trajectory of clinical 
development. We addressed this limitation by identifying a comparable set of products without the PRIME designation within the same therapeutic area.

\section{Future research directions}

A recent study in the US demonstrated that drugs that benefited from the FDA's breakthrough therapy designation had shorter clinical development times.(3) However, a systematic review of breakthrough-designated oncology drugs showed that "there was no evidence that these drugs provide improvements in safety or novelty; nor was there a statistically significant efficacy advantage when compared with non-breakthrough-designated drugs".(33) Whether drugs that benefit from the EMA's PRIME scheme outperform non-PRIMEdesignation products should be evaluated.

Future research should thus scrutinize whether the PRIME scheme is meeting its primary objective of identifying and expediting the development and approval of transformative medicines in Europe. This entails evaluating both the safety and efficacy improvements brought by PRIME medicines, and the speed at which these medicines become available to patients. Whether the clinical benefits delivered by PRIME medicines and gains in time to patient access are aligned with the regulatory and economic advantages provided by the scheme should be assessed. Rigorously evaluating the safety and efficacy of novel therapies becomes even more crucial when they reach the patients faster.

\section{Conclusion}

EMA's PRIME scheme aims to facilitate faster development and approval of promising medicines, as part of a broader effort to ensure early patient access to medicines that fulfil a high unmet need. In its first 2 years, PRIME eligibility was granted based on early clinical studies, which largely incorporated uncontrolled, non-randomised designs, and surrogate markers. There 
was no difference in the proportion of trials which were controlled or blinded before or after eligibility, though numerically fewer trials adopted a robust design after. On the other hand, significantly more trials included clinical endpoints to measure efficacy or quality of life outcomes after PRIME eligibility. Overall, studies that were initiated before and after PRIME designation had similar sample sizes. There was no statistically significant difference between PRIME and non-PRIME drugs. Future research should examine if the scheme can effectively identify truly transformative medicines and bring them to market faster. 


\section{Study Highlights}

What is the current knowledge on the topic?

- EMA recently introduced the Priority Medicines (PRIME) scheme to provide early and extensive regulatory input on drug development plans of selected promising drugs.

- Drugs are eligible for inclusion if they have the potential to target an important unmet medical need.

What question does this study address?

- What is the evidence base on which EMA determines PRIME eligibility?

- What are the characteristics of studies initiated before and after PRIME designation?

- Do the trials for PRIME drugs differ from those of comparable products without PRIME designation?

What does this study add to our knowledge?

- EMA relied primarily on nonrandomised study designs with surrogate measures to determine the eligibility of drugs.

- For eligible drugs, PRIME designation was not associated with the use of clinical endpoints and quality of life outcomes.

- Clinical evidence generated on PRIME products was not significantly different from that on comparable non-PRIME products.

How this might change clinical pharmacology or translational science?

- Future translational research should evaluate both the comparative safety and efficacy of PRIME medicines, and the speed with which they reach the European market. 


\section{Authors Contributions}

HN conceived and designed the study. TJH gave feedback on the methods and framing of the study. EN and SAS independently collected data and categorised the endpoints. HN resolved dissensions in categorisation of endpoints. EN completed the statistical analyses and drafted the manuscript. HN provided extensive comments and revisions on the manuscript. HN, TJH, SAS, and EN contributed to subsequent iterations. All authors provided critical input on the manuscript and approved the final version for publication. $\mathrm{HN}$ is guarantor. 


\section{References}

1. Davis C, Abraham J. Unhealthy Pharmaceutical Regulation: Innovation, POlitics and Promisory Science. Palgrave Macmillan; 2013.

2. FDA. Fact Sheet; Breakthrough Therapies [Internet]. 2018. Available from: https://www.fda.gov/regulatoryinformation/lawsenforcedbyfda/significantamendmentst othefdcact/fdasia/ucm329491.htm

3. Hwang T, Darrow J, Kesselheim A. The FDA's expedited programs and clinical development times for novel therapeutics, 2012-2016. JAMA [Internet]. 2017 Dec 5;318(21):2137-8. Available from: http://dx.doi.org/10.1001/jama.2017.14896

4. Mullard A. PRIME time at the EMA. Nat Rev Drug Discov [Internet]. Nature Publishing Group, a division of Macmillan Publishers Limited. All Rights Reserved.; 2017 Mar 30;16:226. Available from: http://dx.doi.org/10.1038/nrd.2017.57

5. European Medicines Agency. PRIME: Priority Medicines [Internet]. 2018 [cited 2018 Dec 17]. Available from: https://www.ema.europa.eu/en/human-regulatory/researchdevelopment/prime-priority-medicines

6. Hwang TJ, Sokolov E, Franklin JM, Kesselheim AS. Comparison of rates of safety issues and reporting of trial outcomes for medical devices approved in the European Union and United States: cohort study. BMJ [Internet]. BMJ Publishing Group Ltd.; 2016 Jun 28;353:i3323-i3323. Available from: https://www.ncbi.nlm.nih.gov/pubmed/27352914

7. European Commission. Register of Designated Orphan Medicinal Products [Internet]. 2018 [cited 2018 Aug 5]. Available from: http://ec.europa.eu/health/documents/community-register/html/alforphreg.htm)

8. Tse T, Fain KM, Zarin DA. How to avoid common problems when using ClinicalTrials.gov in research: 10 issues to consider. BMJ. 2018;361:1-8.

9. Pregelj L, Hwang TJ, Hine DC, Siegel EB, Barnard RT, Darrow JJ, et al. Precision Medicines Have Faster Approvals Based On Fewer And Smaller Trials Than Other Medicines. Health Aff [Internet]. Health Affairs; 2018 May 1;37(5):724-31. Available from: https://doi.org/10.1377/hlthaff.2017.1580

10. Downing NS, Aminawung JA, Shah ND, Krumholz HM, Joseph S. Ross M. Clinical Trial Evidence Supporting FDA Approval of Novel Therapeutic Agents, 2005-2012. JAMA. 2014;311(4):368-77.

11. Naci H, Smalley KR, Kesselheim AS. Characteristics of preapproval and postapproval studies for drugs granted accelerated approval by the US Food and Drug Administration. JAMA - J Am Med Assoc. 2017;318(7):626-36.

12. EMA. First two CAR-T cell medicines recommended for approval in the European Union [Internet]. 2018. Available from: https://www.ema.europa.eu/en/news/first-twocar-t-cell-medicines-recommended-approval-european-union

13. ChemoCentryx. Avacopan Conditional Marketing Authorization Application Accepted for Regulatory Review by European Medicines Agency [Internet]. 2018. Available from: http://ir.chemocentryx.com/news-releases/news-release-details/avacopan-conditionalmarketing-authorization-application

14. BluebirdBio. bluebird bio Announces European Medicines Agency's Acceptance of Marketing Authorization Application for LentiGlobin ${ }^{\mathrm{TM}}$ Gene Therapy for the Treatment of Transfusion-Dependent $\beta$-Thalassemia [nternet]. 2018. Available from: http://investor.bluebirdbio.com/news-releases/news-release-details/bluebird-bioannounces-european-medicines-agencys-acceptance

15. EMA. Advanced therapy medicinal products: Overview [Internet]. 2019 [cited 2019 Jun 5]. Available from: https://www.ema.europa.eu/en/humanregulatory/overview/advanced-therapy-medicinal-products-overview

16. EMA. Enhanced early dialogue to facilitate accelerated assessment of PRIority Medicines ( PRIME) [Internet]. 2018. Available from: 
https://www.ema.europa.eu/documents/regulatory-procedural-guideline/enhancedearly-dialogue-facilitate-accelerated-assessment-priority-medicines-prime_en.pdf

17. Sculpher M, Claxton K. Establishing the Cost-Effectiveness of New Pharmaceuticals under Conditions of Uncertainty - When Is There Sufficient Evidence ? Value Heal [nternet]. International Society for Pharmacoeconomics and Outcomes Research (ISPOR).; 2005;8(4):433-46. Available from: http://dx.doi.org/10.1111/j.15244733.2005.00033.x

18. Tafuri G, Pagnini M, Moseley J, Massari M, Petavy F, Behring A, et al. How aligned are the perspectives of EU regulators and HTA bodies? A comparative analysis of regulatoryHTA parallel scientific advice. Br J Clin Pharmacol [Internet]. John Wiley \& Sons, Ltd (10.1111); 2016 Oct 1;82(4):965-73. Available from: https://doi.org/10.1111/bcp.13023

19. Hatswell AJ, Baio G, Berlin JA, Irs A, Freemantle N. Regulatory approval of pharmaceuticals without a randomised controlled study: analysis of EMA and FDA approvals 1999-2014. BMJ Open. 2016 Jun;6(6):e011666.

20. Nicotera G, Sferrazza G, Serafino A, Pierimarchi P. The Iterative Development of Medicines Through the European Medicine Agency's Adaptive Pathway Approach . Vol. 6, Frontiers in Medicine . 2019. p. 148.

21. Tang H, Foster NR, Grothey A, Ansell SM, Goldberg RM, Sargent DJ. Comparison of Error Rates in Single-Arm Versus Randomized Phase II Cancer Clinical Trials. J Clin Oncol. 2010;28(11):1936-41.

22. Ciani O, Buyse M, Garside R, Pavey T, Stein K, Sterne JAC, et al. Comparison of treatment effect sizes associated with surrogate and final patient relevant outcomes in randomised controlled trials: meta-epidemiological study. BMJ Br Med J [Internet]. 2013 Jan 29;346. Available from: http://www.bmj.com/content/346/bmj.f457.abstract

23. Wallach JD, Ciani O, Pease AM, Gonsalves GS, Krumholz HM, Taylor RS, et al. Comparison of treatment effect sizes from pivotal and postapproval trials of novel therapeutics approved by the FDA based on surrogate markers of disease: a metaepidemiological study. BMC Med [Internet]. 2018;16(1):45. Available from: https://doi.org/10.1186/s12916-018-1023-9

24. Naci H, Ioannidis JPA. How Good Is "Evidence" from Clinical Studies of Drug Effects and Why Might Such Evidence Fail in the Prediction of the Clinical Utility of Drugs? Annu Rev Pharmacol Toxicol [Internet]. Annual Reviews; 2015 Jan 6;55(1):169-89. Available from: https://doi.org/10.1146/annurev-pharmtox-010814-124614

25. Pereira T V, Ioannidis JPA. Statistically significant meta-analyses of clinical trials have modest credibility and inflated effects. J Clin Epidemiol. United States; 2011 Oct;64(10):1060-9.

26. Pereira T V, Horwitz RI, Ioannidis JPA. Empirical evaluation of very large treatment effects of medical interventions. JAMA. United States; 2012 Oct;308(16):1676-84.

27. Hwang TJ, Carpenter D, Lauffenburger JC, Wang B, Franklin JM, Kesselheim AS. Failure of Investigational Drugs in Late-Stage Clinical Development and Publication of Trial Results Publication of Drug Failures in Late-Stage Clinical Development Publication of Drug Failures in Late-Stage Clinical Development. JAMA Intern Med [Internet]. 2016 Dec 1;176(12):1826-33. Available from: https://dx.doi.org/10.1001/jamainternmed.2016.6008

28. Hoekman J, Klamer TT, Mantel-Teeuwisse AK, Leufkens HGM, De Bruin ML. Characteristics and follow-up of postmarketing studies of conditionally authorized medicines in the EU. Br J Clin Pharmacol. 2016;213-26.

29. Hoffmann TC, Del Mar C. Patients' expectations of the benefits and harms of treatments, screening, and tests: a systematic review. JAMA Intern Med. United States; 2015 Feb;175(2):274-86.

30. Hoffmann TC, Del Mar C. Clinicians' Expectations of the Benefits and Harms of 
Treatments, Screening, and Tests: A Systematic Review. JAMA Intern Med [nternet]. 2017 Mar 1;177(3):407-19. Available from: https://doi.org/10.1001/jamainternmed.2016.8254

31. Kesselheim A, Woloshin S, Eddings W, JM F, KM R, LM S. Physicians' knowledge about FDA approval standards and perceptions of the "breakthrough therapy" designation. JAMA [Internet]. 2016 Apr 12;315(14):1516-8. Available from: http://dx.doi.org/10.1001/jama.2015.16984

32. Krishnamurti T, Woloshin S, Schwartz LM, Fischhoff B. A Randomized Trial Testing US Food and Drug Administration "Breakthrough" LanguageTesting US FDA "Breakthrough" LanguageLetters. JAMA Intern Med [Internet]. 2015 Nov 1;175(11):1856-8. Available from: https://dx.doi.org/10.1001/jamainternmed.2015.5355

33. Hwang TJ, Franklin JM, Chen CT, Lauffenburger JC, Gyawali B, Aaron S, et al. Efficacy, Safety , and Regulatory Approval of Food and Drug Administration - Designated Breakthrough and Nonbreakthrough Cancer Medicines. 2018;(September 2014).

34. EMA. Accelerated Assessment [Internet]. 2019 [cited 2019 Jun 3]. Available from: https://www.ema.europa.eu/en/human-regulatory/marketing-authorisation/acceleratedassessment

35. EMA. Pre-authorisation guidance. 2018. 


\section{Figure Legend}

Figure 1: Timeline of clinical studies evaluating PRIME drugs

\section{Supplementary Information}

(Supplementary Tables.PDF)

Supplementary Tables S1 and S2 


\begin{tabular}{ll}
\hline Regulatory pathway & Primary objective \\
\hline $\begin{array}{l}\text { Accelerated } \\
\text { assessment(34) }\end{array}$ & $\begin{array}{l}\text { Aims at reducing the time from regulatory application to approval for products of } \\
\text { major interest for public health or therapeutic innovation }\end{array}$ \\
\hline $\begin{array}{l}\text { Approval under } \\
\text { exceptional } \\
\text { circumstances(35) }\end{array}$ & $\begin{array}{l}\text { Gives a path to market for medicines that could never meet the standard evidence } \\
\text { requirements on risk-benefit profile because of the rarity of the disease, the present } \\
\text { state of scientific knowledge, or the inability to collect safety or efficacy information } \\
\text { in accordance to medical ethics }\end{array}$ \\
\hline $\begin{array}{l}\text { Conditional } \\
\text { marketing }\end{array}$ & $\begin{array}{l}\text { Allows to give patient access to medicines with a likely positive risk-benefit profile } \\
\text { before all the data normally required for authorisation is available, when the medicine } \\
\text { has the potential to fulfil an important unmet medical need }\end{array}$ \\
\hline $\begin{array}{l}\text { Priority Medicines } \\
\text { (PRIME)(5) }\end{array}$ & $\begin{array}{l}\text { Aims at shortening the time to market for medicines that have the potential of } \\
\text { delivering "a major therapeutic advantage over existing treatments" or addressing an } \\
\text { unmet medical need by better matching development plans with regulatory evidence } \\
\text { requirements and shortening the regulatory evaluation }\end{array}$ \\
\hline
\end{tabular}




\begin{tabular}{|c|c|c|c|c|c|}
\hline $\begin{array}{l}\text { Name } \\
\text { Substance type }\end{array}$ & $\begin{array}{l}\text { Trial } \\
\text { supporting } \\
\text { PRIME } \\
\text { (NCT \#) }\end{array}$ & $\begin{array}{l}\text { Therapeutic } \\
\text { indication } \\
\text { (Therapeutic area) }\end{array}$ & $\begin{array}{l}\text { Date of } \\
\text { orphan } \\
\text { designation }\end{array}$ & Existing treatments & $\begin{array}{l}\text { FDA } \\
\text { BTD }\end{array}$ \\
\hline $\begin{array}{l}\text { A4250 } \\
\text { Chemical }\end{array}$ & 02963077 & $\begin{array}{l}\text { Treatment of } \\
\text { Progressive Familial } \\
\text { Intrahepatic Cholestasis } \\
\text { (Gastroenterology- } \\
\text { Hepatology) }\end{array}$ & $17 / 07 / 2012$ & $\begin{array}{l}\text { No approved treatment } \\
\text { Supportive care } \\
\text { Curative transplant }\end{array}$ & No \\
\hline $\begin{array}{l}\text { AAV2/8- } \\
\text { hCARp.hCNG } \\
\text { B3 (A002) } \\
\text { Advanced } \\
\text { therapy } \\
\end{array}$ & 03001310 & $\begin{array}{l}\text { Treatment of } \\
\text { achromatopsia } \\
\text { associated with defects } \\
\text { in CNGB3 } \\
\text { (Ophthalmology) }\end{array}$ & $11 / 11 / 2015$ & $\begin{array}{l}\text { No approved treatment } \\
\text { Supportive care }\end{array}$ & No \\
\hline $\begin{array}{l}\text { Aducanumab } \\
\text { (BIIB037) } \\
\text { Biological } \\
\end{array}$ & 01677572 & $\begin{array}{l}\text { Treatment of } \\
\text { Alzheimer's disease } \\
\text { (Neurology) }\end{array}$ & - & $\begin{array}{l}\text { Treatment approved: } \\
\text { symptom management }\end{array}$ & No \\
\hline $\begin{array}{l}\text { AMT-060, } \\
\text { AMT-061 } \\
\text { Advanced } \\
\text { therapy }\end{array}$ & 02396342 & $\begin{array}{l}\text { Treatment of severe } \\
\text { haemophilia B } \\
\text { (Haematology - } \\
\text { Hemostaseology) }\end{array}$ & $\begin{array}{l}\text { 21/03/2018 } \\
\text { (AMT-061) }\end{array}$ & Approved treatment & Yes \\
\hline $\begin{array}{l}\text { APG } 101 \\
\text { Biological }\end{array}$ & 01071837 & $\begin{array}{l}\text { Treatment of } \\
\text { glioblastoma } \\
(\text { Oncology })\end{array}$ & $23 / 08 / 2017$ & Approved treatment & No \\
\hline
\end{tabular}

$\begin{array}{lllll}\begin{array}{l}\text { AT132 } \\ \text { Advanced } \\ \text { therapy }\end{array} & 03199469 & \begin{array}{l}\text { Treatment of X-linked } \\ \text { Myotubular Myopathy } \\ \text { (Other) }\end{array} & 10 / 08 / 2015 & \begin{array}{l}\text { No approved treatment } \\ \text { Supportive care }\end{array}\end{array}$

\begin{tabular}{|c|c|c|c|c|c|}
\hline $\begin{array}{l}\text { Axibactagene } \\
\text { ciloleucel } \\
\text { (KTE-C19) } \\
\text { Advanced } \\
\text { therapy } \\
\end{array}$ & 02601313 & $\begin{array}{l}\text { Treatment of adult } \\
\text { patients with relapsed or } \\
\text { refractory mantle cell } \\
\text { lymphoma } \\
\text { (Oncology) }\end{array}$ & $09 / 10 / 2015$ & $\begin{array}{l}\text { Approved treatments } \\
\text { Curative HSCT }\end{array}$ & No \\
\hline $\begin{array}{l}\text { Axibactagene } \\
\text { ciloleucel } \\
\text { (KTE-C19) } \\
\text { Advanced } \\
\text { therapy }\end{array}$ & 02348216 & $\begin{array}{l}\text { Treatment of adult } \\
\text { patients with diffuse } \\
\text { large B-cell } \\
\text { lymphoma (DLBCL) } \\
\text { who have not responded } \\
\text { to their prior therapy, or } \\
\text { have had disease } \\
\text { progression after } \\
\text { autologous stem cell } \\
\text { transplant (ASCT) } \\
\text { (Oncology) }\end{array}$ & $16 / 12 / 2014$ & $\begin{array}{l}\text { Approved treatments } \\
\text { Curative HSCT }\end{array}$ & Yes \\
\hline $\begin{array}{l}\text { bb2121 } \\
\text { Advanced } \\
\text { therapy }\end{array}$ & 02658929 & $\begin{array}{l}\text { Treatment of relapsed } \\
\text { and refractory multiple } \\
\text { myeloma patients whose } \\
\text { prior therapy included a } \\
\text { proteasome inhibitor, an } \\
\text { immunomodulatory } \\
\text { agent and an anti-CD38 } \\
\text { antibody } \\
\text { (Oncology) }\end{array}$ & $20 / 04 / 2017$ & $\begin{array}{l}\text { No approved treatment } \\
\text { in } 4 \mathrm{~L} \\
\text { Supportive care } \\
\text { Bone marrow } \\
\text { transplant }\end{array}$ & Yes \\
\hline
\end{tabular}




\begin{tabular}{|c|c|c|c|c|c|}
\hline $\begin{array}{l}\text { BB305 } \\
\text { Advanced } \\
\text { therapy }\end{array}$ & NA & $\begin{array}{l}\text { Treatment of } \\
\text { transfusion-dependent } \\
\text { beta-thalassaemia (also } \\
\text { referred to as beta- } \\
\text { thalassaemia major) } \\
\text { (Haematology - } \\
\text { Hemostaseology) }\end{array}$ & $24 / 01 / 2013$ & $\begin{array}{l}\text { No approved treatment } \\
\text { Supportive care } \\
\text { Curative HSCT }\end{array}$ & Yes \\
\hline $\begin{array}{l}\text { BPS804 } \\
\text { Biological }\end{array}$ & NA & $\begin{array}{l}\text { Treatment of } \\
\text { osteogenesis imperfecta } \\
\text { types I, III and IV } \\
\text { (Other) }\end{array}$ & $27 / 06 / 2016$ & $\begin{array}{l}\text { No approved treatment } \\
\text { Supportive care }\end{array}$ & No \\
\hline $\begin{array}{l}\text { Brexanolone/ } \\
\text { Allopregnanolo } \\
\text { ne } \\
\text { (SAGE-547) } \\
\text { Chemical }\end{array}$ & 02614547 & $\begin{array}{l}\text { Treatment of } \\
\text { Postpartum depression } \\
\text { (Psychiatry) }\end{array}$ & - & $\begin{array}{l}\text { Treatments available } \\
\text { for depression, no } \\
\text { treatment approved for } \\
\text { postpartum depression } \\
\text { specifically }\end{array}$ & Yes \\
\hline $\begin{array}{l}\text { CCX168 } \\
\text { Chemical }\end{array}$ & 01363388 & $\begin{array}{l}\text { Treatment of Patients } \\
\text { with ANCA-Associated } \\
\text { Vasculitis }\end{array}$ & $19 / 11 / 2014$ & Approved treatment & No \\
\hline $\begin{array}{l}\text { EDI200 } \\
\text { Biological }\end{array}$ & NA & $\begin{array}{l}\text { Treatment of X-linked } \\
\text { hypohidrotic ectodermal } \\
\text { dysplasia } \\
\text { (Dermatology) }\end{array}$ & $14 / 12 / 2005$ & No approved treatment & No \\
\hline $\begin{array}{l}\text { Emapalumab } \\
\text { (NI-0501) } \\
\text { Biological }\end{array}$ & NA & $\begin{array}{l}\text { Treatment of primary } \\
\text { haemophagocytic } \\
\text { lymphohistiocytosis } \\
\text { (HLH) } \\
\text { (Haematology - } \\
\text { Hemostaseology) }\end{array}$ & $09 / 06 / 2010$ & $\begin{array}{l}\text { No approved treatment } \\
\text { Supportive care } \\
\text { Curative transplant }\end{array}$ & Yes \\
\hline $\begin{array}{l}\text { Entrectinib } \\
\text { Chemical }\end{array}$ & 02568267 & $\begin{array}{l}\text { Treatment of NTRK } \\
\text { fusion-positive, locally } \\
\text { advanced or metastatic } \\
\text { solid tumours in adult } \\
\text { and paediatric patients } \\
\text { who have either } \\
\text { progressed following } \\
\text { prior therapies or who } \\
\text { have no acceptable } \\
\text { standard therapy } \\
\text { (Oncology) }\end{array}$ & & $\begin{array}{l}\text { Existing treatments but } \\
\text { no other TRK } \\
\text { inhibitors available }\end{array}$ & Yes \\
\hline $\begin{array}{l}\text { Givosiran } \\
\text { (ALN AS1) } \\
\text { Chemical }\end{array}$ & 02452372 & $\begin{array}{l}\text { Prevention of acute } \\
\text { attacks of hepatic } \\
\text { porphyria } \\
\text { (Endocrinology- } \\
\text { Gynaecology-Fertility- } \\
\text { Metabolism) }\end{array}$ & $29 / 08 / 2016$ & $\begin{array}{l}\text { Approved treatment } \\
\text { Supportive care }\end{array}$ & Yes \\
\hline $\begin{array}{l}\text { GSK2857916 } \\
\text { Biological }\end{array}$ & 02064387 & $\begin{array}{l}\text { Treatment of relapsed } \\
\text { and refractory multiple } \\
\text { myeloma patients whose } \\
\text { prior therapy included a }\end{array}$ & $16 / 10 / 2017$ & $\begin{array}{l}\text { Approved treatment } \\
\text { Curative transplant }\end{array}$ & Yes \\
\hline
\end{tabular}


proteasome inhibitor, an

immunomodulatory

agent and an anti-CD38

antibody

(Oncology)

Prevention of graft

\begin{tabular}{llllll} 
Imlifidase & 02224820, & rejection following solid & & \\
(HMED-IdeS) & 02426684, & organ transplantation & 12/01/2017 & Approved treatments & No \\
Biological & 02475551, & $\begin{array}{l}\text { (Immunology- } \\
\text { Rheumatology- } \\
\text { Transplantation) }\end{array}$ & & \\
& 02790437 & & & \\
& & & & \\
\hline
\end{tabular}

Advanced

Treatment of

therapy

02631044

relapsed/refractory

diffuse large B-cell

lymphoma (DLBCL)

$17 / 07 / 2017$

Approved treatments

Curative HSCT

Yes

(Oncology)

$\begin{array}{lllll}\text { LR12 } & 03463044 & \begin{array}{l}\text { Treatment of septic } \\ \text { shock } \\ \text { Chemical }\end{array} & - & \text { Approved treatment }\end{array}$ No

\begin{tabular}{|c|c|c|c|c|c|}
\hline $\begin{array}{l}\text { Lumasiran } \\
\text { (ALN GO1) } \\
\text { Chemical }\end{array}$ & 02706886 & $\begin{array}{l}\text { Treatment of Primary } \\
\text { Hyperoxaluria Type } 1 \\
\text { (Uro-nephrology) }\end{array}$ & $21 / 03 / 2016$ & $\begin{array}{l}\text { No approved treatment } \\
\text { Lifestyle management } \\
\text { Curative transplant }\end{array}$ & Yes \\
\hline $\begin{array}{l}\text { MV-CHIK } \\
\text { vaccine } \\
\text { Biological }\end{array}$ & NA & $\begin{array}{l}\text { Prevention of } \\
\text { Chikungunya fever } \\
\text { (Vaccines) }\end{array}$ & - & $\begin{array}{l}\text { No existing vaccine to } \\
\text { prevent or medicine to } \\
\text { treat } \\
\text { Symptom management }\end{array}$ & No \\
\hline
\end{tabular}

$\begin{array}{llll}\text { Myrcludex B NA } & \text { 19/06/205 No approved treatment No } \\ \text { Chemical } & \begin{array}{l}\text { Treatment of chronic } \\ \text { hepatitis D infection } \\ \text { (Infectious Diseases) }\end{array} & & \end{array}$

\begin{tabular}{|c|c|c|c|c|c|}
\hline $\begin{array}{l}\text { NLA101 } \\
\text { Advanced } \\
\text { therapy }\end{array}$ & 01690520 & $\begin{array}{l}\text { Treatment in } \\
\text { Haematopoietic Stem } \\
\text { Cell Transplantation } \\
\text { (HSCT) } \\
\text { (Immunology- } \\
\text { Rheumatology- } \\
\text { Transplantation) }\end{array}$ & $17 / 01 / 2018$ & Approved treatments & No \\
\hline $\begin{array}{l}\text { NY-ESO- } \\
\text { 1c259T } \\
\text { (GSK3377794) } \\
\text { Advanced } \\
\text { therapy }\end{array}$ & 01343043 & $\begin{array}{l}\text { Treatment of HLA- } \\
\text { A*0201, HLA-A*0205, } \\
\text { or HLA-A*0206 allele } \\
\text { positive patients with } \\
\text { inoperable or metastatic } \\
\text { synovial sarcoma who } \\
\text { have received prior } \\
\text { chemotherapy and } \\
\text { whose tumour expresses } \\
\text { the NY-ESO-1 tumour } \\
\text { antigen } \\
\text { (Oncology) }\end{array}$ & $21 / 03 / 2016$ & Approved treatments & Yes \\
\hline
\end{tabular}




\begin{tabular}{|c|c|c|c|c|c|}
\hline $\begin{array}{l}\text { Olipudase alfa } \\
\text { Biological }\end{array}$ & NA & $\begin{array}{l}\text { Treatment of non- } \\
\text { neurological } \\
\text { manifestations of acid } \\
\text { sphingomyelinase } \\
\text { deficiency } \\
\text { (Endocrinology- } \\
\text { Gynaecology-Fertility- } \\
\text { Metabolism) }\end{array}$ & $05 / 12 / 2016$ & No approved treatment & Yes \\
\hline $\begin{array}{l}\text { Onasemnogen } \\
\text { e abeparvovec } \\
\text { (AVXS-101) } \\
\text { Advanced } \\
\text { therapy } \\
\end{array}$ & 02122952 & $\begin{array}{l}\text { Treatment of paediatric } \\
\text { patients diagnosed with } \\
\text { spinal muscular atrophy } \\
\text { Type } 1 \\
\text { (Neurology) }\end{array}$ & $19 / 06 / 2015$ & $\begin{array}{l}\text { No approved treatment } \\
\text { Supportive care }\end{array}$ & Yes \\
\hline $\begin{array}{l}\text { Polatuzumab } \\
\text { vedotin } \\
\text { Biological }\end{array}$ & 02257567 & $\begin{array}{l}\text { Treatment of relapsed } \\
\text { and refractory patients } \\
\text { with diffuse large B cell } \\
\text { lymphoma } \\
\text { (Oncology) }\end{array}$ & $16 / 04 / 2018$ & $\begin{array}{l}\text { Approved treatments } \\
\text { Curative HSCT }\end{array}$ & Yes \\
\hline $\begin{array}{l}\text { Rapastinel } \\
\text { (GLYX-13) } \\
\text { Chemical }\end{array}$ & NA & $\begin{array}{l}\text { Adjunctive treatment of } \\
\text { major depressive } \\
\text { disorder } \\
\text { (Psychiatry) }\end{array}$ & - & Approved treatments & Yes \\
\hline $\begin{array}{l}\text { Seladelpar } \\
\text { (MBX-8025) } \\
\text { Chemical }\end{array}$ & 02609048 & $\begin{array}{l}\text { Treatment of Primary } \\
\text { Biliary Cholangitis } \\
\text { (Gastroenterology- } \\
\text { Hepatology) }\end{array}$ & $16 / 10 / 2017$ & $\begin{array}{l}\text { Approved treatments } \\
\text { Curative transplant }\end{array}$ & No \\
\hline $\begin{array}{l}\text { SPK-9001 } \\
\text { Advanced } \\
\text { therapy }\end{array}$ & 02484092 & $\begin{array}{l}\text { Treatment of } \\
\text { haemophilia B } \\
\text { (Haematology - } \\
\text { Hemostaseology) }\end{array}$ & - & Approved treatments & Yes \\
\hline $\begin{array}{l}\text { Tabelecleucel } \\
\text { (ATA129) } \\
\text { Advanced } \\
\text { therapy }\end{array}$ & NA & $\begin{array}{l}\text { Treatment of patients } \\
\text { with Epstein-Barr Virus- } \\
\text { associated Post } \\
\text { Transplant } \\
\text { Lymphoproliferative } \\
\text { Disorder in the } \\
\text { allogeneic hematopoietic } \\
\text { cell transplant setting } \\
\text { who have failed on } \\
\text { rituximab. }\end{array}$ & $21 / 03 / 2016$ & No approved treatment & Yes \\
\hline $\begin{array}{l}\text { Tasadenoturev } \\
\text { (DNX-2401) } \\
\text { Advanced } \\
\text { therapy }\end{array}$ & NA & $\begin{array}{l}\text { Treatment of recurrent } \\
\text { glioblastoma in patients } \\
\text { for which a gross total } \\
\text { resection is not possible } \\
\text { or advisable, or for } \\
\text { those who refuse further } \\
\text { surgery } \\
\text { (Oncology) }\end{array}$ & $09 / 02 / 2016$ & $\begin{array}{l}\text { Approved treatments } \\
\text { Supportive care }\end{array}$ & $\begin{array}{l}\text { Fast } \\
\text { track }\end{array}$ \\
\hline
\end{tabular}




\begin{tabular}{|c|c|c|c|c|c|}
\hline $\begin{array}{l}\text { Tisagenlecleuc } \\
\text { el } \\
\text { (CTL019) } \\
\text { Advanced } \\
\text { therapy }\end{array}$ & NA & $\begin{array}{l}\text { Treatment of paediatric } \\
\text { patients with relapsed or } \\
\text { refractory B cell acute } \\
\text { lymphoblastic leukaemia } \\
\text { (ALL) } \\
\text { (Oncology) }\end{array}$ & $29 / 04 / 2014$ & $\begin{array}{l}\text { Approved treatments } \\
\text { Curative HSCT }\end{array}$ & Yes \\
\hline $\begin{array}{l}\text { V920 } \\
\text { (BPSC-1001) } \\
\text { Immunological }\end{array}$ & NA & $\begin{array}{l}\text { Vaccination against } \\
\text { Ebola (Zaire strain) } \\
\text { (Vaccines) }\end{array}$ & - & Supportive care & Yes \\
\hline $\begin{array}{l}\text { Valoctocogene } \\
\text { Roxaparvovec } \\
\text { (BMN 270) } \\
\text { Advanced } \\
\text { therapy }\end{array}$ & 02576795 & $\begin{array}{l}\text { Treatment of } \\
\text { haemophilia A } \\
\text { (Haematology - } \\
\text { Hemostaseology) }\end{array}$ & $21 / 03 / 2016$ & Approved treatments & Yes \\
\hline $\begin{array}{l}\text { Vocimagene } \\
\text { amiretrorepvec } \\
\text { (TOCA511) } \\
\text { Advanced } \\
\text { Therapy }\end{array}$ & NA & $\begin{array}{l}\text { Treatment of high grade } \\
\text { glioma } \\
\text { (Oncology) }\end{array}$ & $26 / 02 / 2018$ & Approved treatments & Yes \\
\hline $\begin{array}{l}\text { Voxelotor } \\
\text { (GBT440) } \\
\text { Chemical }\end{array}$ & $\begin{array}{l}03041909 \\
02285088\end{array}$ & $\begin{array}{l}\text { Treatment of Sickle Cell } \\
\text { Disease } \\
\text { (Haematology - } \\
\text { Hemostaseology) }\end{array}$ & $18 / 11 / 2016$ & $\begin{array}{l}\text { Approved treatment } \\
\text { Curative HSCT }\end{array}$ & Yes \\
\hline
\end{tabular}




\begin{tabular}{|c|c|c|}
\hline $\begin{array}{l}\text { Name } \\
\text { Substance type }\end{array}$ & $\begin{array}{l}\text { Size of } \\
\text { population } \\
\text { analysed }\end{array}$ & Magnitude of effects forming the basis of PRIME designation \\
\hline
\end{tabular}

\section{A4250}

Chemical

No efficacy results identified

AAV2/8-
hCARp.hCNGB3
(A002)
Advanced therapy

Advanced therapy

\section{Designation granted based on pre-clinical data only No information identified}

Adjusted change from baseline on the Clinical Dementia Rating-Sum of Boxes (CDR-SB): demonstrated dose-dependent slowing of clinical progression with aducanumab treatment at one year (dose-response,

Aducanumab

Biological 165 $\mathrm{P}<0.05)$

Composite neuropsychological test battery and Free and Cued Selective Reminding Test free recall: no changes from baseline at one year but skewed non-normal (floor) effects at baseline observed

AMT-060, AMT-
061
Advanced therapy

Annualized FIX use: reduced by $81 \%$ from baseline Mean Annualized Spontaneous Bleeding Rate (ASBR): decreased from $9.8 \%$ to $4.6 \%(53 \%)$

PFS-6 rates: 3.8\% (95\%-CI: 0.1 - 19.6) in the reirradiation group (rRT), $20.7 \%$ (95\%-CI: 11.2 - 33.4) in the rRT+APG101 group ( $\mathrm{p}=0.04)$

Asunercept

Biological

Median PFS: 2.5 (95\%-CI: 2.3-3.8) months and 4.5 (95\%-CI: 3.7-5.4) months, HR $=0.49$ (95\% CI: 0.27-0.88, $\mathrm{p}=0.0162)$

Cox regression analysis adjusted for tumour size for death of any cause: $\mathrm{HR}=0.60$ (95\% CI: 0.36-1.01) $(\mathrm{p}=0.0559)$ for $\mathrm{rRT}+\mathrm{APG101}$

$\begin{array}{lll}\text { AT132 } & 3 \text { (interim } & \begin{array}{l}\text { Children's Hospital of Philadelphia Infant Test of Neuromuscular } \\ \text { Advanced therapy }\end{array} \\ \text { results) } & \begin{array}{l}\text { Disorders (CHOP-INTEND) score increased from baseline for } 2 \text { of the } \\ 3 \text { patients }\end{array}\end{array}$

\section{Avacopan}

Chemical

\begin{tabular}{lll}
\hline & N $=111$ & ORR: $82 \%$ \\
enrolled, 110 & CRR: $54 \%$ \\
Axicabtagene & $(99 \%)$ & With a median follow-up of 15.4 months, 42\% of the patients continued \\
ciloleucel & successfully & to have a response, with 40\% continuing to have a complete response. \\
Advanced therapy & $\begin{array}{l}\text { manufactured, } \\
\text { to } 101(91 \%)\end{array}$ & Higher CAR T-cell levels in blood associated with response. \\
& OS rate at 18 months: $52 \%$ \\
& Deaths: 3 \\
\hline
\end{tabular}

\section{No efficacy results identified}

Axicabtagene

Ciloleucel

Advanced therapy 


\begin{tabular}{|c|c|c|}
\hline $\begin{array}{l}\text { Brexanolone } \\
\text { Chemical }\end{array}$ & 21 & $\begin{array}{l}\text { Mean reduction in Hamilton Rating Scale for Depression (HAM-D) total } \\
\text { score at } 60 \mathrm{~h} \text { from baseline: } 21.0 \text { points (SE } 2.9 \text { ) in the SAGE- } 547 \text { group, } \\
8.8 \text { points (SE } 2.8 \text { ) in the placebo group (difference }-12 \cdot 2,95 \% \mathrm{CI} \text { - } \\
20 \cdot 77 \text { to }-3 \cdot 67 ; \mathrm{p}=0 \cdot 0075 \text {; effect size } 1.2 \text { ) }\end{array}$ \\
\hline $\begin{array}{l}\text { Dialnubicel } \\
\text { Advanced therapy }\end{array}$ & Not reported & $\begin{array}{l}\text { "The results of this study demonstrated that infusion of dilanubicel } \\
\text { [NLA101] was safe and led to faster neutrophil and platelet recovery } \\
\text { with excellent long-term survival ( } 86 \% \text { vs. } 66 \% \text { in a concurrent control } \\
\text { group)" }\end{array}$ \\
\hline
\end{tabular}

(Results from integrated analysis of pivotal phase II STARTRK-2, phase

\section{Entrectinib}

Chemical
I STARTRK-1 and phase I ALKA trials; PRIME designation based mostly on STARTRK-2)

ORR: $77.4 \%$ in non-small cell lung cancer

DoR: 24.6 months.

intracranial ORR: $55.0 \%$ in central nervous system cancer

\begin{tabular}{|c|c|c|}
\hline $\begin{array}{l}\text { Givosiran } \\
\text { Chemical }\end{array}$ & 4 & $\begin{array}{l}\text { Results pertaining to Cohort } 1(\mathrm{~N}=4,2.5 \mathrm{mg} / \mathrm{kg} \text { given once-quarterly) } \\
\text { "Meaningful reductions in the number and frequency of porphyria } \\
\text { attacks" } \\
\text { Mean decrease in the annualized attack rate compared with the run-in } \\
\text { phase: } 74 \% \\
\text { Mean reduction in annualized hemin administration: } 75 \% \\
\text { Maximum attack-free interval (i.e., greatest period of time between } \\
\text { porphyria attacks): } \sim 10.5 \mathrm{x} \text { that observed during the run-in phase }\end{array}$ \\
\hline $\begin{array}{l}\text { GSK2857916 } \\
\text { Biological }\end{array}$ & $\begin{array}{l}35 \\
\text { (Results } \\
\text { pertaining to } \\
\text { the dose- } \\
\text { expansion } \\
\text { cohort) }\end{array}$ & $\begin{array}{l}\text { ORR: } 21(60 \cdot 0 \% ; 95 \% \text { CI } 42 \cdot 1-76 \cdot 1) \text { of } 35 \text { patients achieved an overall } \\
\text { response }\end{array}$ \\
\hline
\end{tabular}

\section{Imlifidase}

Biological

ORR (reduction or elimination of donor-specific antibodies permitting HLA-incompatible Transplantation): 24 of 25 patient

\begin{tabular}{|c|c|c|}
\hline $\begin{array}{l}\text { JCAR017 } \\
\text { Advanced therapy }\end{array}$ & 44 & $\begin{array}{l}\text { ORR: } 86 \%(38 / 44) \\
\text { CRR: } 59 \%(26 / 44) \\
\text { 3-month ORR: } 66 \%(21 / 32) \text {, } \\
\text { 3-month CRR: } 50 \%(16 / 32) \\
\text { Of patients in response at } 3 \text { months, } 90 \%(9 / 10) \text { continue in response at } \\
6 \text { months }\end{array}$ \\
\hline $\begin{array}{l}\text { LR12 } \\
\text { Chemical }\end{array}$ & & $\begin{array}{l}\text { Designation granted based on pre-clinical data only } \\
\text { No information identified }\end{array}$ \\
\hline $\begin{array}{l}\text { Lumasiran } \\
\text { Chemical }\end{array}$ & $\begin{array}{l}3 \text { (Result } \\
\text { pertaining to } \\
\text { low-dose } \\
\text { cohort) }\end{array}$ & $\begin{array}{l}>50 \% \text { decreases in urinary oxalate excretion relative to baseline: all } \\
\text { patients } \\
\text { Mean maximal reduction for all patients in this initial low dose cohort: } \\
66 \%\end{array}$ \\
\hline
\end{tabular}




$\begin{array}{lll}\text { NY-ESO-1c259T } & 12 \text { (Result } & \text { ORR: 50\% (1 CR; } 5 \text { PR) } \\ \text { (GSK3377794) } & \text { pertaining to } & \text { Time to response: 6 wk (range 4-9) } \\ \text { Advanced therapy } & \text { cohort 1) } & \begin{array}{l}\text { Median DoR: 31 wk (range 13-72). } \\ \text { (Other cohorts not continued or ongoing) }\end{array}\end{array}$

\section{Onasemnogene abeparvovec}

Advanced therapy
15

EFS: all 15 patients alive and event-free at 20 months of age, as compared with a rate of survival of $8 \%$ in a historical cohort CHOP INTEND score: rapid increase from baseline followed gene delivery in the high-dose cohort, with an increase of 9.8 points at 1 month and 15.4 points at 3 months, as compared with a decline in this score in a historical cohort

\section{Polatuzumab} vedotin

Biological 80

CR: 40 for Polatuzumab (Pola) + Bendamustine and Rituximab (BR) vs 15 for BR alone $(\mathrm{p}=0.012)$

Median PFS: $6.7 \mathrm{mo}(4.9 ; 11.1)$ for Pola $+\mathrm{BR}$ vs $2 \mathrm{mo}(1.5 ; 3.7)$ for BR alone $(\mathrm{p}<0.0001)$ mOS: 11.8mo (9.5; NR) for Pola+BR vs $4.7(3.7 ; 8.3)$ for BR alone $(\mathrm{p}=$ $0.0008)$

\section{2 in placebo} group, 13 in seladelpar 50

Seladelpar

Chemical mg group, 10 in seladelpar $200 \mathrm{mg}$ group
SPK-9001

Advanced therapy
10
Mean changes from baseline in alkaline phosphatase: -2\% (SD 16) in placebo group, $-53 \%$ (14) in seladelpar $50 \mathrm{mg}$ group, -63\% (8) in seladelpar $200 \mathrm{mg}$ group $(\mathrm{p}<0.0001$ for both groups vs placebo, $\mathrm{p}=0 \cdot 1729$ between the two seladelpar groups)

Mean annualized bleeding rate: 11.1 events per year [range: 0 to 48 ] before vector administration vs. 0.4 events per year [range, 0 to 4 ] after administration $(\mathrm{p}=0.02)$

Mean factor dose: 2908 IU per kilogram [range, 0 to 8090] before vector administration vs. 49.3 IU per kilogram [range, 0 to 376] after administration $(\mathrm{p}=0.004)$

No use of factor: 8 of 10 participants No bleeds after vector administration: 9 of 10 participants

Median annualized bleeding rate: decreased from 16 events before the study to 1 event after gene transfer among participants who had

7

Valoctocogene Roxaparvovec Advanced therapy
(Results pertaining to high-dose cohort previously received prophylactic therapy Factor VIII use: ceased in all the participants in this cohort by week 22 Sustained normalization of factor VIII activity level over a period of 1 year: achieved in six of seven participants who received a high dose Stabilization of hemostasis: all Reduction in factor VIII use: all, deemed "profound"

Cohort 1, 28

days of voxelotor $500 / 700 / 1000$

$\begin{array}{ll}\text { Voxelotor } & \mathrm{mg} / \text { day: } \mathrm{N}= \\ \text { Chemical } & 38 ; \text { Cohort } 2, \\ & 90 \text { days of } \\ & \text { voxelotor } \\ & 700 / 900 \\ & \mathrm{mg} / \text { day: } \mathrm{N}= \\ & 16\end{array}$

"All patients who received multiple doses of voxelotor for $\geq 28$ days experienced hematologic improvements including increased haemoglobin and reduction in haemolysis and percent of sickled red cells" 
CI: Confidence Interval; CRR: Complete Response Rate; DoR: Duration of Response; EFS: Event Free Survival; HR: Hazard Ratio; ORR: Overall Response Rate; OS: Overall Survival; PFS: Progression Free Survival; PR: Partial Response 
Table 3: Comparison of trial design and endpoints before and after PRIME-eligibility

\begin{tabular}{|c|c|c|c|c|c|c|c|c|c|c|c|c|c|}
\hline \multirow[b]{2}{*}{$\begin{array}{c}\text { Trial } \\
\text { characteristic }\end{array}$} & \multirow[b]{2}{*}{$\begin{array}{l}\text { Randomis } \\
\text { ed and } \\
\text { controlled }\end{array}$} & \multicolumn{2}{|c|}{ Comparator } & \multicolumn{2}{|l|}{ Design } & \multicolumn{3}{|c|}{ Endpoint } & \multicolumn{4}{|c|}{ Efficacy outcome* } & \multirow[b]{2}{*}{$\begin{array}{l}\text { Sample } \\
\text { size }\end{array}$} \\
\hline & & Placebo & $\begin{array}{l}\text { Active or } \\
\text { SoC }\end{array}$ & Blinded & Safety & PK/PD & Efficacy & QoL & $\begin{array}{l}\text { Resource } \\
\text { Use }\end{array}$ & Clinical & $\begin{array}{l}\text { Clinical } \\
\text { scale }\end{array}$ & Surrogate & \\
\hline \multicolumn{14}{|l|}{ BEFORE } \\
\hline $\begin{array}{l}\text { All } \\
(\mathrm{n}=102)\end{array}$ & $\begin{array}{c}41(40.2) \\
{[30.7-49.7]}\end{array}$ & $\begin{array}{c}31(30.4) \\
{[21.5-39.3]}\end{array}$ & $\begin{array}{c}10(9.8) \\
{[4.0-15.6]}\end{array}$ & $\begin{array}{c}34(33.3) \\
{[24.2-42.5]}\end{array}$ & $\begin{array}{c}83(81.4) \\
{[73.8-88.9]}\end{array}$ & $\begin{array}{c}41(40.2) \\
{[30.7-49.7]}\end{array}$ & $\begin{array}{c}87(85.3) \\
{[78.4-92.2]}\end{array}$ & $\begin{array}{l}11(10.8) \\
{[4.8-16.8]}\end{array}$ & $\begin{array}{l}0(0) \\
{[0-0]}\end{array}$ & $\begin{array}{c}33(37.9) \\
{[37.7-48.1]}\end{array}$ & $\begin{array}{c}23(26.4) \\
{[17.2-35.7]}\end{array}$ & $\begin{array}{c}72(82.8) \\
{[74.8-90.7]}\end{array}$ & $\begin{array}{c}154 \\
{[23-128]}\end{array}$ \\
\hline $\begin{array}{l}\text { Late-stage trials } \\
(\mathrm{n}=47)\end{array}$ & $\begin{array}{c}26(55.3) \\
{[41.1-69.5]}\end{array}$ & $\begin{array}{c}18(38.3) \\
{[24.4-52.2]}\end{array}$ & $\begin{array}{c}8(17.0) \\
{[6.3-27.8]}\end{array}$ & $\begin{array}{c}21(44.7) \\
{[30.5-58.9]}\end{array}$ & $\begin{array}{c}31(66.0) \\
{[52.4-79.5]}\end{array}$ & $\begin{array}{c}9(19.1) \\
{[7.9-30.4]}\end{array}$ & $\begin{array}{c}45(95.7) \\
{[90.0-100]}\end{array}$ & $\begin{array}{c}4(8.5) \\
{[0.5-16.5]}\end{array}$ & $\begin{array}{l}0(0) \\
{[0-0]}\end{array}$ & $\begin{array}{c}11(24.4) \\
{[11.9-37.0]}\end{array}$ & $\begin{array}{c}18(40.0) \\
{[25.7-54.3]}\end{array}$ & $\begin{array}{c}31(68.9) \\
{[55.4-82.4]}\end{array}$ & $\begin{array}{c}248 \\
{[30-282]}\end{array}$ \\
\hline \multicolumn{14}{|l|}{ AFTER } \\
\hline All $(\mathrm{n}=36)$ & $\begin{array}{c}9(25.0) \\
{[10.9-39.1]}\end{array}$ & $\begin{array}{c}6(16.7)[4.5- \\
28.8]\end{array}$ & $\begin{array}{c}3(8.3) \\
{[0-17.4]}\end{array}$ & $\begin{array}{c}7(19.4) \\
{[6.5-32.4]}\end{array}$ & $\begin{array}{c}24(66.7) \\
{[51.3-82.1]}\end{array}$ & $\begin{array}{c}12(33.3) \\
{[17.9-48.7]}\end{array}$ & $\begin{array}{c}33(91.7) \\
{[82.6-100]}\end{array}$ & $\begin{array}{c}16(44.4) \\
{[28.2-60.7]}\end{array}$ & $\begin{array}{c}2(5.6) \\
{[0-13.0]}\end{array}$ & $\begin{array}{c}26(78.8) \\
{[64.8-92.7]}\end{array}$ & $\begin{array}{c}12(36.4) \\
{[20.0-52.8]}\end{array}$ & $\begin{array}{c}27(81.8) \\
{[68.7-95.0]}\end{array}$ & $\begin{array}{c}139 \\
{[29-161]}\end{array}$ \\
\hline $\begin{array}{l}\text { Late-stage trials } \\
(\mathrm{n}=30)\end{array}$ & $\begin{array}{c}9(30.0) \\
{[13.6-46.4]}\end{array}$ & $\begin{array}{c}6(20.0) \\
{[5.7-34.3]}\end{array}$ & $\begin{array}{l}3(10.0) \\
{[0-20.7]}\end{array}$ & $\begin{array}{c}7(23.3) \\
{[8.2-38.5]}\end{array}$ & $\begin{array}{c}20(66.7) \\
{[49.8-83.5]}\end{array}$ & $\begin{array}{c}8(26.7) \\
{[10.8-42.5]}\end{array}$ & $\begin{array}{c}30(100) \\
{[100-100]}\end{array}$ & $\begin{array}{c}14(46.7) \\
{[28.8-64.5]}\end{array}$ & $\begin{array}{c}2(6.7) \\
{[0-15.6]}\end{array}$ & $\begin{array}{c}23(76.7) \\
{[61.5-91.8]}\end{array}$ & $\begin{array}{c}11(36.7) \\
{[19.4-53.9]}\end{array}$ & $\begin{array}{c}24(80.0) \\
{[65.7-94.3]}\end{array}$ & $\begin{array}{c}162 \\
{[36-196]}\end{array}$ \\
\hline
\end{tabular}

Number of trials (proportion), [95\% confidence interval]; For the sample size, the interquartile range is reported

Note: Long-term follow-up studies excluded; *Proportion of trials including an efficacy endpoint

PK/PD: Pharmacokinetics/ pharmacodynamics; QoL: quality of life; SoC: standard of care 
Table 4: Comparison of trial design and endpoints for products with and without PRIME designation

\begin{tabular}{|c|c|c|c|c|c|c|c|c|c|c|c|c|c|}
\hline \multirow{2}{*}{ Trial characteristic } & \multicolumn{2}{|l|}{ Design } & \multicolumn{2}{|c|}{ Comparator } & \multicolumn{4}{|l|}{ Endpoint } & \multicolumn{4}{|c|}{ Efficacy outcome* } & \multirow[t]{2}{*}{$\begin{array}{l}\text { Sample } \\
\text { size }\end{array}$} \\
\hline & RCT & Blinded & $\begin{array}{l}\text { Active } \\
\text { or SoC }\end{array}$ & Placebo & Safety & PK/PD & Efficacy & QoL & $\begin{array}{l}\text { Resourc } \\
\text { e Use }\end{array}$ & Clinical & $\begin{array}{l}\text { Clinical } \\
\text { scale }\end{array}$ & $\begin{array}{l}\text { Surrogat } \\
\text { e }\end{array}$ & \\
\hline \multicolumn{14}{|l|}{ BEFORE } \\
\hline PRIME (n = 24) & $8(33.3)$ & $7(29.2)$ & $1(4.2)$ & $7(29.2)$ & $22(91.7)$ & $12(50.0)$ & $20(83.3)$ & $1(4.2)$ & $0(0)$ & $9(45.0)$ & $1(5.0)$ & $19(95.0)$ & $\begin{array}{l}154 \\
{[24-151]}\end{array}$ \\
\hline $\begin{array}{l}\text { Non-PRIME } \\
(\mathrm{n}=18)\end{array}$ & $13(72.2)$ & $13(72.2)$ & $0(0)$ & $13(72.2)$ & $17(94.4)$ & $6(33.3)$ & $12(66.7)$ & $2(11.1)$ & $0(0)$ & $2(16.7)$ & $1(8.3)$ & $11(91.7)$ & $\begin{array}{l}326 \\
{[64-500]}\end{array}$ \\
\hline $\mathrm{p}$ & 0.028 & 0.012 & $>1$ & 0.012 & $>1$ & 0.343 & 0.147 & 0.573 & $>1$ & 0.075 & $>1$ & $>1$ & 0.094 \\
\hline \multicolumn{14}{|l|}{ AFTER } \\
\hline PRIME (n = 9) & $3(33.3)$ & $2(22.2)$ & $1(11.1)$ & $2(22.2)$ & $6(66.7)$ & $1(11.1)$ & $9(100)$ & $3(33.3)$ & $0(0)$ & $7(77.8)$ & $3(33.3)$ & $9(100)$ & $\begin{array}{l}222 \\
{[31-350]}\end{array}$ \\
\hline $\begin{array}{l}\text { Non-PRIME } \\
(\mathrm{n}=8)\end{array}$ & $4(50)$ & $2(25)$ & $2(25)$ & $2(25)$ & $7(87.5)$ & $6(75)$ & $5(62.5)$ & $1(12.5)$ & $0(0)$ & $4(80)$ & $0(0)$ & $2(40)$ & $\begin{array}{l}58 \\
{[22-89]}\end{array}$ \\
\hline $\mathrm{p}$ & 0.637 & $>1$ & 0.576 & $>1$ & 0.576 & 0.015 & 0.082 & 0.576 & $>1$ & $>1$ & 0.258 & 0.027 & 0.140 \\
\hline
\end{tabular}

Number of trials (proportion); For the sample size, the interquartile range is reported

Note: Long-term follow-up studies excluded; *Proportion of trials including an efficacy endpoint

PK/PD: Pharmacokinetics/ pharmacodynamics; QoL: quality of life; SoC: standard of care 
Time to/from PRIME designation (days)

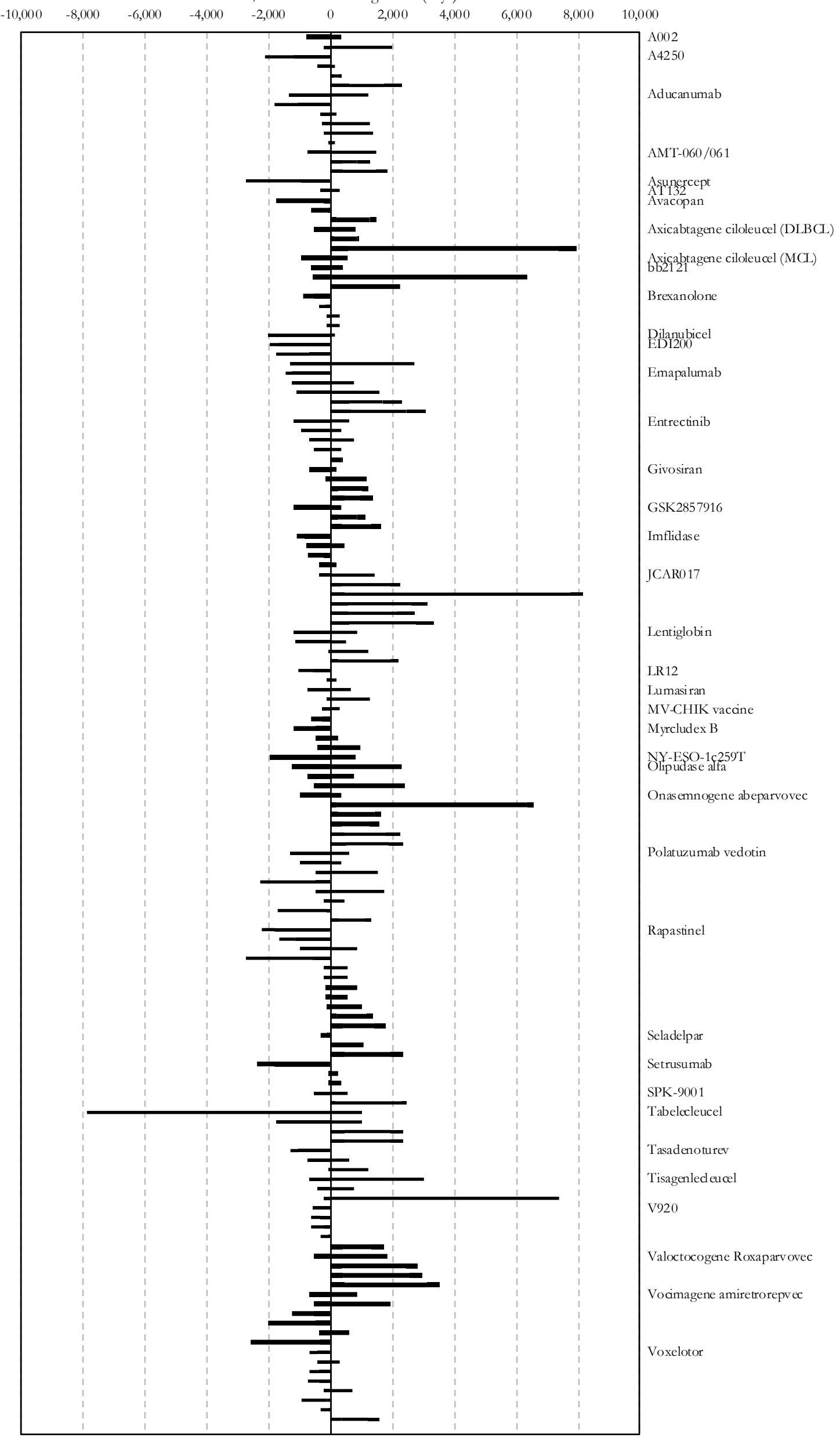

